\title{
PENERAPAN GERAKAN LITERASI SEKOLAH DI SEKOLAH DASAR
}

\section{Wendri Wiratsiwi}

Universitas PGRI Ronggolawe Tuban

Email: wendriwiratsiwi3489@gmail.com

\begin{tabular}{l}
\hline Info Artikel \\
\hline SejarahArtikel: \\
$\begin{array}{l}\text { Diserahkan 23 Maret } 2020 \\
\text { Direvisi } 27 \text { April } 2020 \\
\text { Disetujui15 Mei 2020 }\end{array}$ \\
\hline Keywords: \\
school literacy movement, \\
reading aloud, \\
heart reading \\
\hline
\end{tabular}

\begin{abstract}
This study aims to obtain information about the application of GLS or the School Literacy Movement in Cluster 01 Elementary School, Singgahan District, Tuban Regency.

This study uses qualitative research with a case study research design. Data collection techniques used are observation, interviews and documentation.

The results showed that, the application of the School Literacy Movement in the Cluster 01 Elementary School in Singgahan District was still at the habituation stage, namely 1) through reading aloud for about 15 minutes before learning for the low class and heart reading for the high class, 2) making a reading corner in each class, and 3) provide school library facilities. In implementing the School Literacy Movement there are still some obstacles including: 1) the lack of reading books; 2) lack of interest in reading students; 3) the teacher has not fully carried out this activity; 4) lack of guidance from the local education office about this School Literacy Movement; 5) and parents of students who are somewhat indifferent to the needs of children in order to support the School Literacy Movement. Whereas efforts to overcome obstacles during the implementation of the School Literacy Movement are: 1) seeking the fulfillment of reading books and library facilities by allocating funds for School Operational Costs (BOS); 2) SDN Saringembat I frees students to choose whenever students want to read, it does not have to be 15 minutes pre-learning so that a carpet is provided in the reading corner for them to use as a base for seating when they want to read; 3) SDN Saringembat I in order to improve the quality of GLS implementation by discussing and collaborating with other schools on the occasion when gathering at the Teacher Working Group activities in group 01 and the Principal Working Group $(K K K S)$ or to other schools that are also GLS reference schools.
\end{abstract}

\begin{abstract}
Abstrak
Penelitian ini bertujuan untuk memperoleh informasi tentang penerapan GLS atau Gerakan Literasi Sekolah di Sekolah Dasar Gugus 01 Kecamatan Singgahan Kabupaten Tuban.

Penelitian ini menggunakan jenis penelitian kualitatif dengan desain penelitian studi kasus. Teknik pengumpulan data yang digunakan yaitu observasi, wawancara dan dokumentasi.

Hasil penelitian menunjukkan bahwa penerapan Gerakan Literasi Sekolah di Sekolah Dasar Gugus 01 Kecamatan Singgahan masih pada tahap pembiasaan yaitu 1) melalui kegiatan membaca nyaring selama kurang lebih 15 menit sebelum pembelajaran untuk kelas rendah dan membaca hati untuk kelas tinggi, 2) membuat pojok baca di setiap kelas, dan 3) menyediakan fasilitas perpustakaan sekolah. Dalam penerapan Gerakan Literasi Sekolah ini masih terdapat beberapa kendala diantaranya yaitu : 1) masih kurangnya buku bacaan; 2) kurangnya minat membaca siswa; 3) guru belumsepenuhnyamenjalankankegiatanini; 4) kurangnya pembinaan dari pihak dinas pendidikan setempat tentang Gerakan Literasi Sekolah ini; 5) serta orang tua siswa yang agak acuh terhadap kebutuhan anak dalam rangka menunjang Gerakan Literasi Sekolah. Sedangkan upaya-upaya untuk mengatasi kendala selama penerapan Gerakan Literasi Sekolah yaitu: 1) mengupayakan pemenuhan buku bacaan dan fasilitas perpustakaan dengan mengalokasikan dana Bantuan Operasional Sekolah (BOS); 2) SDN Saringembat I membebaskan siswa untuk memilih kapan saja siswa mau membaca, tidak harus pada 15 menit pra pembelajaran sehingga disediakan karpet pada pojok baca untuk mereka gunakan sebagai alas tempat duduk saat mereka ingin membaca; 3) SDN Saringembat I dalam rangka membenahi kualitas pelaksanaan GLS dengan cara berdiskusi serta bekerjasama dengan sekolah lain pada kesempatan saat berkumpul pada kegiatan Kelompok Kerja Guru di gugus 01 dan Kelompok Kerja Kepala Sekolah (KKKS) atau ke sekolah lain yang juga menjadi sekolah rujukan GLS.
\end{abstract}

(C) 2020 Universitas Muria Kudus 
Wendri Wiratsiwi

PENERAPAN GERAKAN LITERASI SEKOLAH DI SEKOLAH DASAR

REFLEKSI EDUKATIKA : Jurnal Ilmiah Kependidikan, Nomor 10,Volume 2, Juni 2020, hlm. 230-238

\section{PENDAHULUAN}

Literasi merupakan sebuah gerakan yang diluncurkan oleh Kementerian Pendidikan dan Kebudayaan. Secara umum menurut Hartati (2017:302) literasi adalah sebuah istilah untuk kemampuan dan keterampilan yang dimiliki seseorang untuk memahami atau mengerti, mengolah, serta menggunakan informasi yang diterimauntuk berbagai keadaan. Oleh karena itu, tentunya literasi sangat berhubungan dengan kehidupan siswa, baik di lingkungan rumah, sekolah atau masyarakat. Sehingga literasi baik digunakan untuk menumbuhkan budi pekerti yang luhur.

Menurut Kemendikbud (2017) literasi didefinisikan sebagai a) kemampuan melakukan kegiatan baca, tulis, berhitung, dan bicara, serta kemampuan mencari informasi dan menggunakannya; b) kegiatan sosial yang dalam penerapannya dipengaruhi oleh berbagai kondisi; c) kegiatan pembelajaran yang didalamnya terdapat kegiatan membaca, menulis, menghitung yang digunakan untuk memikirkan, menyelidiki, menanyakan, dan mengkritik semua hal yang telah dipelajari; dan d) penggunaan bacaan yang memiliki variasi dalam hal subjek, aliran, dan tingkat kerumitan bahasa.

Dalam menghadapi abad 21, peserta didik memerlukan beberapa keterampilan diantaranya adalah literasi dasar, kompetensi, dan karakter. Literasi dasar berhubungan dengan kemampuan siswa menggunakan keterampilan berliterasi yang dimilikinya dalam kehidupan sehari-hari. Kompetensi sendiri yaitu kemampuan siswa dalam menghadapi tantangan yang semakin kompleks. Selanjutnya, karakter adalah bagaimana sikap siswa dalam menghadapi perubahan lingkungan (Satgas GLS Ditjen Dikdasmen, 2016:1). Lima nilai pokok dalam penguatan pendidikan karakter di Indonesia diantaranya yaitu nilai religius, nilai nasionalisme, nilai mandiri, nilai gotong royong dan nilai integritas (Depdikbud, 2016).

Beberapa jenis literasi yang menjadi fokus dalam upaya peningkatan kecakapan multiliterasi siswa sehingga nilai-nilai karakter dapat terwujud yaitu literasi sains, numerasi, baca dan tulis, finansial, digital, serta budaya dan kewargaan. Diharapkan melalui pembelajaran multiliterasi yang dipadukan dengan kompetensi yang harus dimiliki pada abad-21 yaitu kompetensi kreativitas, kompetensi komunikasi, kompetensi berpikir kritis, dan kompetensi kolaborasi serta lima nilai karakter dalam penguatan pendidikan karakter yang telah dijelaskan sebelumnya dapat menjadi bekal peserta didik dalam menghadapi abad-21.

Hubungan antara kompetensi pada abad 21, nilai karakter, serta multiliterasi dapat dilihat pada Gambar 1 di bawah ini:

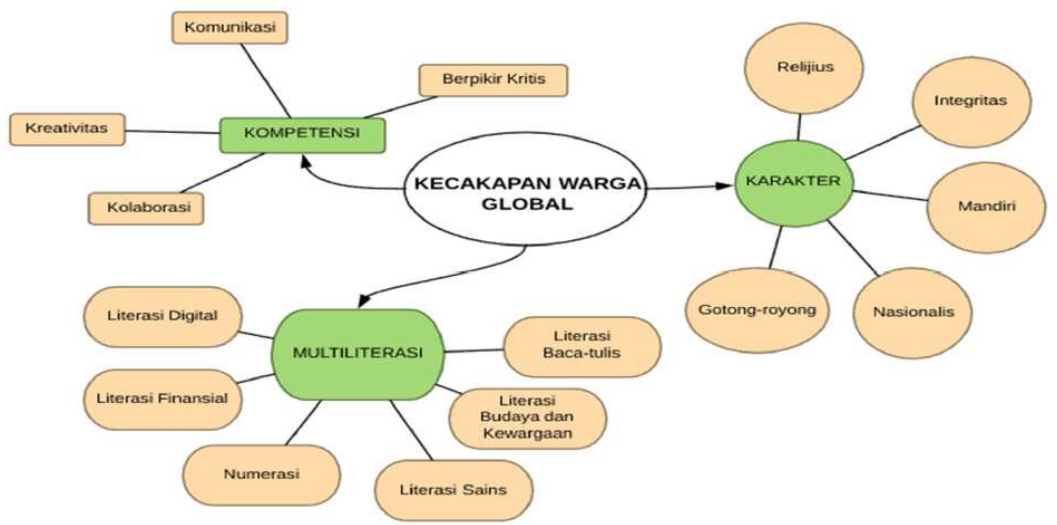

Gambar 1. Hubungan multileterasi, kompetensi, dan nilai karakter utama

Kesadaran warga sekolah sendiri tentang manfaat kemampuan literasi yang mereka miliki untuk kehidupan mereka masih sangat rendah. Selain itu, masih terbatasnya penggunaan buku atau bacaan lain di sekolah selain buku pelajaran sehingga menyebabkan kegiatan pengembangan kemampuan literasi untuk guru dan siswa belum maksimal. Selama ini kegiatan membaca yang dilakukan di sekolah-sekolah masih sebatas membaca buku pelajaran dan sedikit yang membaca buku atau bacaan jenis lainnya. 


\author{
Wendri Wiratsiwi \\ PENERAPAN GERAKAN LITERASI SEKOLAH DI SEKOLAH DASAR \\ REFLEKSI EDUKATIKA : Jurnal Ilmiah Kependidikan, Nomor 10,Volume 2, Juni 2020, hlm. 230-238
}

Disisi lain, hasil riset PIRLS (Progress in International Reading Literacy Study) denganmelakukan evaluasi terhadap kemampuan membaca siswa kelas IV, menunjukkan bahwa dalam kategori membaca, Indonesia menempati urutan ke 45 dari 48 negara yang diriset. Artinya kemampuan membaca peserta didik di Indonesia masih rendah (Satgas GLS Ditjen Dikdasmen, 2016).

PISA (Programme for International Student Assessment) juga melakukan riset juga mengevaluasi kemampuan membaca, matematika, dan sains siswa berusia 15 tahun, menunjukkan bahwa Indonesia pada menempati urutan ke 57 dari 65 negarayang diriset pada tahun 2009, menempati urutan ke 64 dari 65 negara yang diriset pada tahun 2012, serta menempati urutan ke 64 dari 70 negara yang diriset pada tahun 2015. Berdasarkan data tersebut, menunjukkan bahwa kekmampuan membaca, dan kemampuan Matematika serta Sains peserta didik di Indonesia juga masih rendah (Satgas GLS Ditjen Dikdasmen, 2016).

INAP atau Indonesia National Assessment Program juga melakukan riset melalui kegiatan evaluasi terhadap kemampuanmembaca, matematika, dan sains siswa. Berdasarkan riset tersebut menunjukkan bahwa nilai kemampuan membaca di Indonesia masih sebesar $46,83 \%$ yang artinya kemampuan membaca siswa didik di Indonesia juga masih kurang (Satgas GLS Ditjen Dikdasmen, 2016:2).

Berdasarkan hubungan antara kompetensi pada abad 21, nilai karakter, serta multiliterasi di atas dan berdasarkan tiga hasil riset di atas menjadi dasar Kemdikbud melalui Permendikbud No 23 Tahun 2015 mengenalkan sebuah gerakan yang diberi nama
Gerakan Literasi Sekolah dengan harapan dapat menumbuhkan dan mengembangkan sikap yang baik dan berbudi pekerti luhur melalui pembelajaran yang multiliterasi, karena pada dasarnya tujuan pendidikan bukan hanya menghasilkan seseorang yang hanya memiliki kecerdasan intelektual, melainkan juga menghasilkan orang yang memiliki kecerdasan sosial, emosional, serta spiritual.

Menurut Faizah (2016), dasar pengembangan Gerakan Literasi Sekolah ini yaitu Nawacita nomor $5,6,8,9$ yang intinya yaitu meningkatkan kualitas hidup, produktivitas dan daya saing masyarakat Indonesia agar tidak tertinggal dengan bangsa-bangsa lain terutama di Asia, dan memperkuat kebinekaan serta restorasi sosial masyarakat Indonesia, dan karakter bangsa yang harus direvolusi. Menurut Teguh (2017) Gerakan Literasi Sekolah atau GLS merupakan kegiatan yang mengikutsertakan semua pihak yang berhubungan dengan pendidikan yaitu mulai dari seluruh warga sekolah (kepala sekolah, guru, tenaga kependidikan, dan siswa), pengawas sekolah, wali murid/ orang tua siswa, komite sekolah, masyarakat dalam hal ini yaitu tokoh masyarakat yang dapat menjadi teladan dan memberi pengalaman dunia usaha,penerbit, akademisi, media massa, sertaorang-orang yang berkepentingan di bawah koordinasi Dirjen Pendidikan Dasar dan Menengah Kemdikbud.

Ada tiga tahapan literasi yang dapat diterapkan di sekolah untuk menumbuhkan literasi sendiri yaitu pertama tahap pembiasaan, kedua tahap pengembangan dan ketiga adalah tahap pembelajaran. Ketiga tahapan tersebut dapat dilihat pada Gambar 2 berikut:
Tahap pengembangan literasi dapat dilakukan melalui kegiatan nonakademik
Kegiatan intrakulikuler/ pembelajaran menggunakan strategi literasi

Gambar 2. Tahapan Literasi 
Adapun penjelasan tentang tahapantahapan gerakan literasi sekolah adalah sebagai berikut; yaitupertama adalah tahap pembiasaan. Pada tahap ini dapat dilakukan dengan pembiasaan membaca selama kurang lebih 15 menit sebelum pembelajaran. Untuk mendukung kegiatan ini tentunya sekolah diharapkan dapat menyediakan buku-buku selain buku pelajaran dan bahan bacaan lain sehingga siswa tertarik untuk membaca.

Kedua, adalah tahap pengembangan, yaitu tahap selanjutnya setelah kebiasaan membaca mulai terbentuk, pengembangan kemampuan literasi siswa dapat dilakukan melalui berbagai kegiatan literasi. Seperti yang dikemukan Wandasari (2017) berdasarkan hasil penelitiannya yaitu bahwa kegiatan kegiatan pengembangan literasi dapat dilakukan melalui kegiatan mendiskusikan suatu bacaan, membaca cerita dengan intonasi, menulis cerita, dan mengadakan kegiatan festival literasi.

Ketiga, setelah tahap pembiasaan dan pengembangan ada tahap pembelajaran, dimana sekolah dapat menyelenggarakan berbagai kegiatan yang dapat mempertahankan kemampuan literasi siswa dan minat baca siswa. Seperti yang dicontohkan Faizah (2016) dalam penelitiannya, yaitu melalui kegiatan pembinaan kemampuan menulis cerita, kemampuan membaca sertamulai memasukkan kegiatan literasi dalam tahappembelajaran.

Ada banyak penelitian tentang penerapan Gerakan Literasi Sekolah, diantaranya yaitu penelitian yang dilakukan oleh Nopilda dan Kristiawan (2018) dimana Gerakan Literasi Sekolah (GLS)telah dilakukan sejak tahun 2016 di SMK Negeri 1 Suak Tapeh melalui pembelajaran multiliterasi, sehingga kegiatan menulis, membaca, dan berbicara bahasa di SMK tersebut sudah memasuki memasuki tahap pengembangan dan bahkan memasuki tahapa pembelajaran serta melalui kegiatan GLS ini telah meningkatkan budaya literasi dan karakter siswa mulai tumbuh menjadi kreatif dan inovatif.

Penelitian tentang penerapan Gerakan Literasi Sekolah juga dilakukan oleh Hidayat, dkk (2018) di SDN 2 Sitirejo dan SDN 4 Panggungrejo. Berdasarkan hasil penelitian di dua sekolah tersebut menunjukkan bahwa pelaksanaan GLS belum maksimal, masih ada beberapa faktor penghambat yang belum teratasi sehingga dampak positif terhadap minat membaca siswa masih kurang, hal tersebut dikarenakansiswa belum banyak yang terlihatmembaca buku bacaan selama berada di lingkungan sekolah.

Selanjutnya ada Antasari (2017) yang melakukan penelitian tentang implemetasi Gerakan Literasi Sekolah di sebuah sekolah yaitu MI Muhammadiyah Gandatapa di daerah Sumbang Banyumas, dimana di sekolah tersebut pelaksanaan kegiatan GLS masih pada tahap pembiasaan yaitu melalui kegiatan membacakan buku teks dengan keras, menyediakan lingkungan yang kaya literasi walaupun dengan fasilitas yang minim, menyediakan fasilitas berupa kolam ikan dan kebun yang disekitarnya kaya akan literasi, serta melibatkan masyarakat luas dalam implementasinya. Komunikasi antara pihaksekolahdengan orang tuacukup baik dalammemberikanmotivasibelajarpadaanak.

Berdasarkan beberapa uraian sebelumnya, penelitian ini bertujuan untuk mendalami pelaksanaan program Gerakan Literasi Sekolah di Sekolah Dasar di Gugus 01 Kecamatan Singgahan Tuban dan kendala yang dihadapi selama penerapannya serta upaya yang sudah atau akan dilakukan pihak sekolah untuk mengatasinya.

\section{METODE PENELITIAN}

Penelitian ini menggunakan jenis penelitian kualitatif. Desain penelitian yang digunakan dalam penelitian ini yaitu studi kasus.

Lokasi penelitian dalam penelitian ini yaitu SDN Saringembat I dan SDN Mulyorejo Kecamatan Singgahan Kabupaten Tuban.

Peneliti mengambil kedua sekolah tersebut dengan alasan yang pertama dalam studi penduhuluan kedua sekolah tersebut mengklaim telah melaksanakan Gerakan Literasi Sekolah. Sedangkan alasan kedua yaitu kedua sekolah tersebut berada pada situasi lingkungan yang berbeda yaitu SDN Mulyorejo berada pada lingkungan pedesaan sedangkan SDN Saringembat I berada pada lingkungan perkotaan yang fasilitas dan kondisi pelaksanaan pendidikan perkotaan lebih mendukung, oleh karena itu peneliti tertarik untuk melihat perbedaan implementasi GLS di dua kondisi lingkungan tersebut. Penelitian ini dilakukan selama satu semester dari bulan JuliDesember 2019. 
Penelitian ini menggunakan dua sumber data yaitu sumber data primer dan sumber data sekunder. Sumber data primer dalam penelitian ini meliputi 1) data hasil wawancara dengan kepala sekolah, guru, peserta didik dan tenaga kependidikan, dan 2) data hasil pengamatan tentang implementasi GLS di lapangan yaitu tentang fisik, dokumen, dan kondisi yang ada.

Sumber data sekunder dalam penelitian ini meliputi jurnal-jurnal ilmiah dan buku-buku referensi yang dapat digunakan untuk melengkapi hasil penelitian.

Subjek penelitian dalam penelitian ini meliputi kepala sekolah, guru, peserta didik, penjaga perpustakaan dan tenaga kependidikan.

Teknik pengumpulan data dalam penelitian ini yaitu (a) observasi; (b) wawancara; dan (c) studi dokumentasi. Instrumen pengumpulan data yang digunakan dalam penelitian ini yaitu (a) lembar observasi; (b) lembar wawancara; dan (c) pedoman studi dokumentasi.

Ada empat kriteria dalam pengecekan keabsahan data selama pengumpulan data, yaitu pertama kredibilitas atau derajat kepercayaan, kedua transferabilitas atau keteralihan, ketiga dependabilitas atau kebergantungan, dan konfirmabilitas atau kepastian (Ulfatin, 2015).

Analisis data yang digunakan dalam penelitian ini yaitu reduksi data, penyajian data, serta penarikan kesimpulan. Ketiga langkah tersebut merupakan analisis data model Milesdan Huberman (Ahmadi, 2014).

\section{HASIL DAN PEMBAHASAN}

Pelaksanaan Program Gerakan Literasi Sekolah di SDN Saringembat I dan SDN Mulyorejo

Berdasarkan hasil wawancara dengan Kepala Sekolah, guru, peserta didik, penjaga perpustakaan dan tenaga kependidikan di dua sekolah tersebut diperoleh informasi bahwa sosialisasi tentang Kegiatan Literasi Sekolah telah dilakukan sejak tahun 2017. Sosialisasi ini pada awalnya bertujuan untuk menyamakan persepsi atau pandangan serta komitmen kepala sekolah, guru, peserta didik, penjaga perpustakaan dan tenaga kependidikan tentang pelaksanaan kegiatan literasi di sekolah.

Setelah kegiatan sosialisasi tersebut, dengan demikian diyakini bahwa kepala sekolah, guru-guru, peserta didik, penjaga perpustakaan dan tenaga kependidikan telah memiliki pengetahuan tentang program gerakan literasi sekolah.

Berikut informasi pelaksanaan Gerakan Literasi Sekolah di SDN Saringembat 1 dan SDN Mulyorejo yaitu sebagai berikut:

1. Kegiatan membaca

Kegiatan membaca dalam rangka Gerakan Literasi Sekolah yang dilaksanakan di dua sekolah di atas masih sama-sama pada tahap pembiasaan, dimana kegiatan GLS dilaksanakan melaluikegiatanmembacanyaring selama kurang lebih 15 menit untuk kelas rendah dan membaca dalam hati untuk kelas tinggi sebelum pembelajaran dimulai. Sedangkan yang membedakan kegiatan membaca di dua sekolah tersebut yaitu setelah membaca selama 15 menit, sebagian guru di SDN Saringembat I meminta siswa menulis hasil yang dibaca pada pohon literasi sedangkan di SDN Mulyorejo setelah kegiatan membaca selesai, guru langsung memulai pembelajaran.

2. Membuat pojok baca

Masih dalam rangka pembiasaan Gerakan Literasi Sekolah, berdasarkan hasil pengamatan dan wawancara di kelas-kelas di dua sekolah tersebut dapat diketahui bahwa disetiap kelas terdapat tempat khusus yang berisi buku-buku bacaan siswa yang telah disiapkan masing-masing guru. Tempat tersebut sering disebut sebagai sudut baca atau 'pojok literasi'.

Tujuan guru menyiapkan sudut baca atau pojok literasi yaitu diantaranya agar siswa tertarik untuk sering membaca dan bisa dijadikan sebagai sebuah perpustakaan mini yang nyaman sebagai tempat untuk membaca. Selain buku-buku bacaan untuk siswa, di pojok literasi atau sudut baca tersebut terdapat juga tulisantulisan atau poster yang berisi ajakan untuk membaca dan pentingnya membaca. Di SDN Saringembat I siswa diperkenankan membawa buku-buku bacaan yang mereka miliki di rumah untuk dibaca di sekolah.

Selain untuk menarik minat baca siswa, pembuatan sudut baca atau pojok literasi tersebut juga dapat dijadikan fasilitas dalam kegiatan membaca selama 
kurang lebih 15 menit sebelum pembelajaran.

Meskipun sama-sama memiliki fasilitas pojok baca, akan tetapi fasilitas sudut baca di SDN Saringembat I lebih lengkap dari pada fasilitas sudut baca di SDN Mulyorejo. Pada masing-masing kelas di SDN Saringembat I di pojok bacanya terdapat rak buku dan karpet sedangkan pojok baca di SDN Mulyorejo di masing-masing kelas terdapat meja tetapi hanya beberapa kelas yang memiliki rak buku.

Bahan bacaan di pojok baca jenis fiksi dan nonfiksi di SDN Saringembat I terdapat di semua kelas, akan tetapi untuk di SDN Mulyorejo hanya terlihat di tiga kelas yaitu kelas I, V, dan VI, sedangkan kelas lainnya kebanyakan hanya menyediakan buku pelajaran.

3. Menyediakan fasilitas perpustakaan sekolah.

Dalam rangka mendukung Gerakan Literasi Sekolah yaitu menyediakan bahan bacaan, baik di SDN Saringembat I dan SDN Mulyorejo sama-sama memiliki fasilitas perpustakaan sekolah. Pelaksanaan GLS di dua sekolah tersebut yang dilakukan dalam rangka penyediaan bahan-bahan bacaan diantaranya sebagai berikut:

a. Buku-buku pengayaan di sekolah ditambah

Berdasarkan hasil wawancara peneliti dengan kepala sekolah dan pengelola perpustakaan sekolah dapat diperoleh informasi bahwa SDN Saringembat I dan SDN Mulyorejo memiliki lebih dari 500 eksemplar buku untuk 6 rombongan belajar. Meskipun masih dalam kategori kurang dibandingkan dengan standar ideal perpustakaan Sekolah Dasar yaitu untuk 6 rombongan belajar sebanyak 1000 judul buku dan untuk 12 rombongan belajar sebanyak 1500 judul buku. Sehingga masih perlu ditingkatkan lagi dalam rangka pengisian sudut baca atau pojok literasi.

Jenis buku yang tersedia pada perpustakaan sekolah di SDN Saringembat I dan SDN Mulyorejo terdiri atas buku pelajaran, referensi, dan buku bacaan (pengayaan), akan tetapi tidak melanggan majalah manapun. Sehingga persentasi jumlah buku pengayaan belum mencapai $60 \%$ di masing-masing sekolah tersebut sebagaimana yang telah ditentukan untuk perpustakaan SD. Kondisi tersebut dapat mempengaruhi minat baca, minat kunjung, dan minat meminjam buku diperpustakaan sekolah (Faradina, 2017) .

Selama ini upaya yang telah dilakukan untuk menambah buku-buku pengayaan diperpustakaan yaitu dengan menyisihkan dana BOS (Bantuan Operasional Sekolah) untuk membelinya.

Ternyata gerakan literasi sekolah ini sudah banyak diimplementasikan di beberapa sekolah dasar atau sederajat, seperti hasil penelitian Antasari (2017) di MI Muhammadiyah Gentapa Sumbang Banyumas dimana gerakan literasi sekolah ini diimplementasikan melalui kegiatan membaca buku dengan keras, menyediakan fasilitas yang kaya literasi seperti kebun dan kolam ikan, serta melibatkan masyarakat sekitar dalam program tersebut.

Gerakan literasi sekolah ini ternyata juga berpengaruh terhadap minat baca siswa, berdasarkan hasil penelitian Faradina (2017) tentang pengaruh program gerakan literasi sekolah terhadap minat baca siswa di SD Islam Terpadu Muhammadiyah An-Najah Jatinom Klaten menunjukkan bahwa ada pengaruh yang signifikan antara dari Program GLS dengan minat baca siswa di sekolah tersebut.

Dengan demikian tentunya gerakan literasi sekolah di SDN Saringembat I dan SDN Mulyorejo lebih ditingkatkan kembali.

\section{Kendala Selama Implementasi Gerakan Literasi Sekolah di SDN Saringembat I dan SDN Mulyorejo}

Kendala selama implemetasi GLS di SDN Saringembat I yaitu terbatasnya jumlah buku bacaan yang dimiliki, kualitas pelaksanaan kegiatan GLS karena masih lemahnya sumber daya guru sebagai pelaksana, dan minat baca siswa yang masih rendah. Adapun kendala dalam dimplementasi GLS di SDN Mulyorejo juga masih tentang kurangnya bahan bacaan sebagai prasarana kegiatan membaca, guru yang belum sepenuhnya melaksanakan kegiatan ini, dan juga minat baca siswa yang belum mulai tumbuh.

Kendala yang sama antara kedua sekolah tersebut yaitu keterlibatan dinas 
pendidikan setempat dalam pelaksanaan GLS masih kurang. Kedua sekolah menyampaikan hal tersebut dengan kalimat berbeda yaitu SDN Saringembat I menyampaikan bahwa kegiatan pembinaan terkait GLS hanya dilakukan sekali sewaktu sosialisasi tanpa memantau lebih lanjut tentang pelaksaannya di lapangan.

Sedangkan SDN Mulyorejo juga menyampaikan bahwa selama pelaksaan GLS yang sudah berjalan selama ini, belum pernah ada kunjungan ke sekolah dari dinas yang berwenang untuk melihat pelaksanaan GLS. Sehingga kedua sekolah dalam hal ini sepakat bahwa dinas pendidikan kurang perhatian untuk sekolah terkait pelaksanaan GLS ini. Padahal sudah jelas dalam pedoman Gerakan Literasi Sekolah bahwa tugas dinas pendidikan kabupaten yaitu memantau ketersediaan sarana di tiap sekolah (Wiedarti, 2016).

Kendala berikutnya dalam implementasi GLS ini yaitu peran serta orang tua siswa dalam menunjang GLS ini, dimana masih banyak orang tua yang agak acuh terhadap kebutuhan anak dalam menunjang bahan bacaan yang dapat meningkatkan minat anak untuk membaca.

Masing-masing sekolah telah melakukan upaya untuk mengatasi kendala yang ditemui saat pelaksanaan kegiatan GLS. Upaya-upaya tersebut antara lain yang pertama, SDN Saringembat I dan SDN Mulyorejo telah berupaya memenuhi buku-buku bacaan dan fasilitas perpustakaan dengan mengalokasikan dana Bantuan Operasional Sekolah (BOS) untuk melengkapi kebutuhan terkait GLS, hal ini dapat dilakukan karena dalam petunjuk teknis BOS Permendikbud nomor 26 tahun 2017 membeli buku bacaan merupakan suatu yang dapat diperoleh dari dana BOS sebab dapat menjadi bahan pengayaan bagi siswa.

Hal lain yang dapat dilakukan oleh SDN Saringembat I dan SDN Mulyorejo sebagaimana yang telah dipraktikkan oleh guru kelas II di SDN Mulyorejo yaitu dengan mencetak sendiri bahan bacaannya menggunakan kertas kuarto. Memungkinkan juga dicetak bahan bacaan bergambar akan lebih baik, sebab perlu diingat pula bahwa siswa SD yang masih pada tahap operasional kongkret sudah semestinya menggunakan bahan bacaan yang bergambar karena efeknya lebih kuat daripada yang tidak bergambar.

Kedua, dalam rangka mengatasi masalah minat baca siswa yang masih rendah,
SDN Saringembat I membebaskan siswa untuk memilih kapan saja siswa mau membaca, tidak harus pada 15 menit prapembelajaran, sehingga disediakan karpet pada pojok baca untuk mereka gunakan sebagai alas tempat duduk saat mereka ingin membaca.

Selain itu beberapa guru juga telah berupaya meningkatkan minat membaca siswa melalui pemberian tugas sekolah yang dapat mengharuskan siswa untuk banyak membaca dalam menyelesaikan tugas yang diberikan. Seperti halnya yang diungkapkan Kasiun (2015) dalam penelitiannya yaitu pemberian stimulan atau rangsangan melalui pemberian tugas sekolah oleh guru dimana secara tidak langsung mengharuskan mereka banyak membaca sehingga mereka sendiri akan sadar tentang pentingnya membaca dan minat baca mereka lama-lama akan meningkat.

Ketiga, SDN Saringembat I dalam rangka membenahi kualitas pelaksanaan GLS dengan cara berdiskusi serta bekerjasama dengan sekolah lain pada kesempatan saat berkumpul pada kegiatan Kelompok Kerja Guru di gugus 01 dan Kelompok Kerja Kepala Sekolah (KKKS) atau ke sekolah lain yang juga menjadi sekolah rujukan GLS. Selama ini KKKS memang menjadi wadah perkumpulan kepala sekolah dalam satu gugus untuk membicarakan masalah intrakurikuler terkait implementasi kurikulum mencakup kegiatan belajar mengajar, evaluasi pembelajaran dan sebagainya. Oleh karena GLS juga menunjang kegiatan intrakurikuler dalam hal ini sebagai bahan pengayaan siswa sehingga tepat apabila pembahasan tentang GLS dibawa oleh kepala sekolah pada KKKS.

Penelitian yang dilaksanakan memiliki persamaan dan perbedaan dengan riset Masfuah (2015), penelitian Ismaya (2017) dan riset Suntoro (2019). Adapun persamaannya yaitu pemilihan literasi sebagai ide pokok penelitian. Sedangkan perbedaanya pada fokus dan hasil penelitiannya.

Riset Masfuah (2015) menyimpulkan bahwa terdapat pengaruh yang signifikan antara kecakapn personal (X) dengan kemampuan literasi sains (Y). Hal ini berarti bahwa semakin tinggi tingkat kecakapn personal, semakin tinggi pula kemampuan literasis sains siswa. Nilai koefisien korelasi (rxy) sebesar 0,56 diketahui bahwa terdapat hubungan yang positif dalam taraf sedang antara kecakapn personal dengan kemampuan 
literasi sains. Selain itu, nilai koefisien determinasi (r2) sebesar 0,31 menunjukkan bahwa $31 \%$ kemampuan literasi sains dipengaruhi oeh kecakapan personal melalui hubungan linier, sedangkan $69 \%$ dipengaruhi oleh faktor lain.

Penelitian Ismaya (2017) menunjukkan bahwa pembelajaran konsep ilmu pengetahuan sosial berbasis literasi informasi yang dilaksanakan, bisa diterima dengan baik oleh mahasiswa. Mahasiswa mampu menemukan informasi dan membangun pengetahuan serta pemahaman terhadap konsep-konsep ilmu pengetahuan sosial dengan benar. Konten lokal yang disajikan sebagai bahan pengayaan dalam pembelajaran konsep ilmu pengetahuan sosial turut memperkuat pengetahuan dan pemahaman mahasiswa serta dapat mendukung pencapaian visi Universitas Kebudayaan.

Riset Suntoro (2019) menemukan bahwa (1) kebutuhan informasi guru PAB di Kabupaten Pati secara umum dapat diklasifikasikan menjadi kebutuhan informasi untuk peningkatan kompetensi guru dan kebutuhan informasi untuk peningkatan karier; (2) akses informasi bersumber dari berbagai lokasi, para guru juga telah mampu menganalisis, mengorganisasi, dan menyimpan perolehan informasi dengan baik; (3) guru memanfaatkan hasil literasi informasi dalam kegiatan belajar mengajar di sekolah meskipun mengalami kendala seperti minimnya sarana prasarana penunjang pembelajaran.

\section{SIMPULAN}

Berdasarkan hasil pembahasan sebelumnya, maka simpulan dalam penelitian ini adalah

1. Pelaksanaan GLS atau Gerakan Literasi Sekolah di SDN Saringembat I dan di SDN Mulyorejo masih pada tahap pembiasaan yaitu 1) melalui kegiatan membaca nyaring selama kurang lebih 15 menit sebelum pembelajaran dimulai untuk kelas rendah dan membaca dalam hati untuk kelas tinggi, 2) membuat pojok literasi atau sudut baca di setiap kelas, dan 3) menyediakan fasilitas perpustakaan sekolah.

2. Kendala selama implemetasi Gerakan Literasi Sekolah ini yaitu : 1) masih kurangnya buku bacaan; 2) kurangnya minat membaca siswa; 3) guru belum sepenuhnya menjalankan kegiatan ini; 4) kurangnya pembinaan dari pihak dinas pendidikan setempat tentang Gerakan Literasi Sekolah ini; 5) serta orang tua siswa yang agak acuh terhadap kebutuhan anak dalam rangka menunjang Gerakan Literasi Sekolah.

3. Beberapa upaya yang akan dilakukan untuk mengatasi kendala selama implementasi Gerakan Literasi Sekolah yaitu: 1) mengupayakan pemenuhan buku bacaan dan fasilitas perpustakaan dengan mengalokasikan dana Biaya Operasional Sekolah (BOS) untuk melengkapi kebutuhan terkait GLS; 2) SDN Saringembat I membebaskan siswa untuk memilih kapan saja siswa mau membaca, tidak harus pada 15 menit prapembelajaran sehingga disediakan karpet pada pojok baca untuk mereka gunakan sebagai alas tempat duduk saat mereka ingin membaca; 3) SDN Saringembat I dalam rangka membenahi kualitas pelaksanaan GLS dengan cara berdiskusi serta bekerjasama dengan sekolah lain pada kesempatan saat berkumpul pada kegiatan Kelompok Kerja Guru di gugus 01 dan Kelompok Kerja Kepala Sekolah (KKKS) atau ke sekolah lain yang juga menjadi sekolah rujukan GLS.

\section{DAFTAR PUSTAKA}

Ahmadi, R. 2014. Metodologi Penelitian Kualitatif. Yogyakarta: Ar-Ruzz Media.

Antasari, I. W. 2017. Implementasi Gerakan Literasi Sekolah Tahap Pembiasaan di MI Muhammadiyah Gandatapa Sumbang Banyumas. Libria, 9 (1): 1326.

Faizah, Dewi Utami, et al. 2016. Panduan Gerakan Literasi Sekolah di Sekolah Dasar. Jakarta: Direktorat Jenderal Pendidikan Dasar dan Menengah Kemdikbud RI.

Faradina, N. 2017. Pengaruh Program Gerakan Literasi Sekolah terhadap Minat Baca Siswa di SD Islam Terpadu Muhammadiyah An-Najah Jatinom Klaten. Jurnal Hanata Widya, 6 (8): 6069. 
Hartati, T. 2017. Multimedia in Literacy Development At Remote Elementary Schools in West Java (Multimedia Dalam Pengembangan Literasi Di Sekolah Dasar Terpencil Jawa Barat). Edutech, 15 (3): 301-310.

Hidayat, M. H., dan Basuki, I. A. 2018. Gerakan Literasi Sekolah di Sekolah Dasar. Jurnal Pendidikan: Teori, Penelitian, dan Pengembangan, 3 (6): 810-817.

Ismaya, Erik Aditia. 2017. Pembelajaran Konsep Ilmu Pengetahuan Sosial Berbasis Literasi Informasi Untuk Mendukung Pencapaian Visi Universitas Kebudayaan. Prosiding Aktualisasi Kurikulum 2013 Di Sekolah Dasar Melalui Gerakan Literasi Sekolah Untuk Menyiapkan Generasi Unggul Dan Berbudi Pekerti 15 Maret 2017, 123-134.

Kasiun, S. 2015. Upaya Meningkatkan Minat Baca sebagai Sarana untuk Mencerdaskan Kehidupan Bangsa. Jurnal Pena Indonesia (JPI), 1(1): 7995.

Masfuah, Siti. 2015. Pengaruh Kecakapan Personal Terhadap Literasi Sains Siswa. Refleksi Edukatika : Jurnal Ilmiah Kependidikan, 5 (2).

Nopilda, L., dan Kristiawan, M. 2018. Gerakan Literasi Sekolah Berbasis Pembelajaran Multiliterasi Sebuah Paradigma Pendidikan Abad Ke-21. JMKSP (Jurnal Manajemen, Kepemimpinan, dan Supervisi Pendidikan), 3(2): 216231
Satgas GLS Ditjen Dikdasmen, 2016a. "Strategi Literasi dalam Pembelajaran di Sekolah Dasar (Modul Materi Penyegaran Instruktur Kurikulum 2013)”. Jakarta: Direktorat Jenderal Pendidikan Dasar dan Menengah Kementerian Pendidikan dan Kebudayaan

Sugiyono. 2011. Metode Penelitian Pendidikan Pendekatan Kuantitatif, Kualitatif, dan $R \& D$. Bandung. Alfabeta.

Suntoro. 2019. Literasi Informasi Guru Pendidikan Agama Buddha Dan Implikasinya Dalam Pembelajaran. Refleksi Edukatika : Jurnal Ilmiah Kependidikan, 9 (2): 182-191.

Teguh, M. 2017. Gerakan Literasi Sekolah dasar. Prosiding Seminar Nasional Vol. 15: 18-26.

Tim GLN Kemendikbud, 2017. "Peta Jalan Gerakan Literasi Nasional”. Jakarta: Direktorat Jenderal Pendidikan Dasar dan Menengah Kementerian Pendidikan dan Kebudayaan

Ulfatin, N. 2015. Metode Penelitian Kualitatif di Bidang Pendidikan: Teori dan Aplikasinya. Malang: Media Nusa Creative.

Wandasari, Y. 2017. Implementasi Gerakan Literasi Sekolah (GLS) Sebagai Pembentuk Pendidikan Berkarakter. JMKSP (Jurnal Manajemen, Kepemimpinan, Dan Supervisi Pendidikan), 2 (2): 12-22.

Wiedarti, P., et al. 2016. Desain Induk Gerakan Literasi Sekolah. Jakarta: Direktorat Jenderal Pendidikan Dasar dan Menengah Kementerian Pendidikan dan Kebudayaan 